\title{
Accelerated aging of ipê seeds under controlled conditions of storage ${ }^{1}$
}

\author{
Marília Shibata ${ }^{2}$, Cileide Maria Medeiros Coelho ${ }^{3}$ Luciana Magda de Oliveira ${ }^{3 *}$, \\ Cristhyane Garcia ${ }^{3}$
}

\begin{abstract}
This research was aimed at studying effects of storage and accelerated aging on germination and profile of storage proteins in Handroanthus albus seeds. These were stored into a cold chamber $\left( \pm 8^{\circ} \mathrm{C}\right.$; $\left.\mathrm{RH} \pm 40 \%\right)$ and after periods of $0,3,6,9$, and 12 months of storage, were subjected to accelerated aging for $0,24,48,72$, and 96 hours. Relationships between germination and proteins profile were assessed. Germination test was performed at $25{ }^{\circ} \mathrm{C}$, under constant light. For protein extraction, $125 \mathrm{mg}$ of seeds were macerated in $2 \mathrm{~mL}$ of extraction buffer (1M Tris$\mathrm{HCl}$; $\mathrm{pH} 8.8$ ) and applied to SDS-PAGE polyacrylamide gel at $80 \mathrm{~V} .15 \mathrm{~h}^{-1}$. Twelve month storage, combined with 72 hours accelerated aging have increased germination in approximately $65 \%$ when compared to non-aged seeds or to seeds with $24 \mathrm{~h}$ of accelerated aging. Besides beneficial effects, degradation and synthesis of different proteins were observed. It was concluded that germination of Handroanthus albus seeds, when not subjected to accelerated aging, is favored by storage in cold chamber during three to six months, or from nine to 12 months when subjected to accelerated aging process. Storage proteins may be associated to those increases, and hence further studies are needed.
\end{abstract}

Index terms: yellow "ipê", protein, Tabebuia alba.

\section{Envelhecimento acelerado de sementes de ipê em condições controladas de armazenamento}

\begin{abstract}
RESUMO - Objetivou-se estudar o efeito do armazenamento e do envelhecimento acelerado na germinação e no perfil das proteínas de reserva de sementes de Handroanthus albus. As sementes foram armazenadas em câmara fria e ao 0, 3, 6, 9 e 12 meses submeteu-se ao envelhecimento acelerado por $0,24,48,72$ e $96 \mathrm{~h}$, e avaliou-se a germinação e o perfil proteico. O teste de germinação foi realizado sob luz constante a $25^{\circ} \mathrm{C}$. Para a extração das proteínas, utilizaram-se $125 \mathrm{mg}$ de sementes maceradas com $2 \mathrm{~mL}$ do tampão de extração (1M tris $\mathrm{HCl}$ pH 8,8) e aplicadas em gel SDS-PAGE (3\% e 15\%) a $80 \mathrm{~V} .15 \mathrm{~h}^{-1}$. O armazenamento por 12 meses associado a $72 \mathrm{~h}$ de envelhecimento acelerado aumentaram a germinação em aproximadamente $65 \%$ em relação às sementes não envelhecidas e envelhecidas por $24 \mathrm{~h}$. Associado a este efeito benéfico, observouse a degradação e síntese de diferentes proteínas. Conclui-se que a germinação de sementes de Handroanthus albus não envelhecidas artificialmente é favorecida pelo armazenamento em câmara fria por três ou seis meses, e por nove ou 12 meses, associado ao envelhecimento acelerado. As proteínas de reserva podem estar associadas a este acréscimo e necessitam ser mais bem estudadas.
\end{abstract}

Termos para indexação: ipê-amarelo, proteínas, Tabebuia alba.

\section{Introduction}

The tree of clustered blossoming commonly called
"Yellow Ipê" [Handroanthus albus (Cham.) Mattos; Syn: Tabebuia alba (Cham.) Sandwith], popularly also known by its other common names "Golden Ipê" and "Ipê From

\footnotetext{
${ }^{3}$ Departamento de Engenharia Florestal, UDESC, Caixa Postal 281, 88520-000 - Lages, SC, Brasil.

*Corresponding author<luciana@cav.udesc.br>

${ }^{2}$ Departamento de Fitotecnia, Universidade Federal de Santa Catarina, Caixa Postal 476, 88034-001- Florianópolis, SC, Brasil
} 
the Mountain" is a native Brazilian tree, which occurs in the states of Rio de Janeiro and Minas Gerais and spreads until the state of Rio Grande do Sul (Grose and Olmstead, 2007; Lorenzi, 2002). Due to its exuberant yellow blooming is widely used in landscaping, particularly for ornamentation of sidewalks of streets and avenues; and is also used for recomposing ciliary woods in areas free of inundations (Carvalho, 2003).

To preserve the species and meet the needs of reforestation programs and urban landscaping, seed conservation becomes a necessity. On seed storage, however, it was found a wide variation on physiological quality of seeds in the genus Handroanthus (Carvalho et al., 1976; Kano et al, 1978; Maeda and Matthes, 1984; Figliolia, 1988; Figliolia et al., 1988; Cunha et al., 1992; Kageyama et al., 1992; Mello and Eira, 1995), making difficult the establishment of cultivation techniques for recomposition of degraded areas and seed conservation in germplasm banks (Cabral et al., 2003; Pinto et al., 1986).

In a general way, research works related to seed deterioration during storage stumbles on limitations in the time necessary on performing these studies. One of the technical procedures used to allow for deterioration studies is by artificially aging seeds.

The accelerated aging test consists on subjecting seeds to elevated temperature and relative humidity $\left(42{ }^{\circ} \mathrm{C}\right.$; $100 \% \mathrm{RH}$ ), simulating normal storage conditions, but with an increased speed of deterioration, thus allowing the monitoring of processes involved. Such technique has been used for studying changes on the biochemical, cytological, and physiological conditions of seeds during deterioration process (Jeng and Sung, 1994; Khan et al., 1996; Spinola et al., 2000) as compared to the natural aging process (Ganguli and SenMandi, 1990; Aiazzi et al., 1996; Camargo et al., 2000; Machado-Neto et al., 2001).

After harvest, both during storage or after accelerated aging, seeds may present physiological changes such as formation of chemical compounds and modifications on proteins stored in the seed (Dell'Aquila and Spada, 1994; Bettey and FinchSavage, 1998; Dell'Aquila and Di Turi, 1999; Korotaeva et al., 2001; Al-Niemi and Stout, 2002; Gashaw and Michelsen, 2002; Sun et al., 2002) what can favor the aging process (Shibata et al., 2011). These accumulated reserves are responsible for the vital functions of seeds, besides directly affecting their potential of storage (Marcos-Filho, 2005).

Therefore, the objective of this research work was to quantify effects of storage periods and of accelerated aging time on germination and on reserve proteins profile in seeds of Handroanthus albus aiming at improving the use and conservation of seeds of this species.

\section{Material and Methods}

The experimental work was carried out at the Laboratory for Analyses of Genetics and Seeds, State University of Santa Catarina, Campus of Lages, State of Santa Catarina, Southern Brazil. For that, H. albus seedpods were collected from three different mother-plants at the beginning of dehiscence, with the aid of a pruning shears. The extraction and processing of seeds were manually performed, discarding the visually damaged seeds.

The so processed seeds were stored into transparent polyethylene bags $(22 \mathrm{~cm} \times 32 \mathrm{~cm}$ in dimension, and 20 $\mu \mathrm{m}$ thick), which were then placed into a cold chamber $\left( \pm 8{ }^{\circ} \mathrm{C}\right.$; $\mathrm{RH} \pm 40 \%$ ) on top of cardboard boxes. At each three months storage period $(0,3,6,9$, and 12 months $)$ the percentage of germination and the total proteins profile of seeds subjected or not to accelerated aging were assessed.

For performing the test of accelerated aging, after homogenization of samples, 200 seeds of each sample were evenly distributed, on a single layer, on top of nylon screens (5 mm mesh), placed on the upper part of gerbox type germination boxes containing $40 \mathrm{~mL}$ of distilled water at the bottom. A BOD type seed germinator, adjusted to $42{ }^{\circ} \mathrm{C}$ and $100 \% \mathrm{RH}$, was used for aging seeds during times of 0 (control), 24, 48, 72, and $96 \mathrm{~h}$.

Assessments of moisture content were performed by the oven method at $105 \pm 3{ }^{\circ} \mathrm{C}$, for $24 \mathrm{~h}$, (Brasil, 2009) by using two replications of $1 \mathrm{~g}$ seeds each.

Physiological quality of seeds was assessed by the germination test, using a completely randomized experimental design, with the treatments arranged into a $5 \times 5$ factorial scheme [5 storage periods $(0,3,6,9$, and 12 months $) \mathrm{x}$ 5 incubation periods $(0,24,48,72$, and $96 \mathrm{~h})]$, with four replications of 25 seeds each, for each set of factors (storage period $\mathrm{x}$ incubation time). Seeds were evenly distributed on top of sheets of germination paper $\left(\right.$ Germitest $\left.^{\mathbb{B}}\right)$, moistened with sterile distilled water, in the ratio of $3 \mathrm{~mL}$ of water per 1 $\mathrm{g}$ of dry paper. The set (seeds + paper) were made into rolls and then placed into a BOD type seed germinator, at $25^{\circ} \mathrm{C}$, under constant light. The first count of germination was performed at the $14^{\text {th }}$ day after starting the test and the final counting was performed at the $28^{\text {th }}$ day (Silva et al., 2011), by assessing normal and abnormal seedling and non-germinated seeds, according to Brasil (2009). 
Data were transformed into arc sine $\sqrt{ } \mathrm{x} / 100$ and treatment means were compared by the Tukey test, at $5 \%$ probability.

For electrophoretic analysis of proteins, $125 \mathrm{mg}$ of seeds for each aging time was used. For that, seeds were macerated with $2 \mathrm{~mL}$ of extraction buffer containing $1 \mathrm{M}$ tris-HCL, $\mathrm{pH} 8.8$, for $10 \mathrm{~min}$. and afterwards centrifuged at $14000 \mathrm{rpm}$, for $20 \mathrm{~min}$., at $4^{\circ} \mathrm{C}$, according to methodological standardization proposed by Shibata et al.(2011). The supernatant was poured into micro-tubes and pellet was discarded. For applying into the gel, into the supernatant were added $25 \mu \mathrm{L}$ of proteinic extract $+25 \mu \mathrm{L}$ of sample buffer ( $5 \mathrm{mM}$ glycerol, $1.73 \mathrm{mM}$ sodium dodecyl sulfate (SDS), $1.54 \mathrm{mM}$ tris-HCl, $\mathrm{pH}$ 6.8, $0.036 \mathrm{mM}$ bromophenol blue, and $0.15 \mathrm{mM} \beta$-mercapto-ethanol). To make up the volume to $25 \mathrm{~mL}$, distilled water was added, and the solution was then placed into water-bath with boiling water, for $5 \mathrm{~min}$. A $20 \mu \mathrm{g}$ sample of protein was applied to polyacrylamide gel SDS-PAGE at $15 \%$ (separator gel) and at 3\% (concentrator gel) according to Laemmli (1970), and in agreement with changes performed by Ma and Bliss (1978). The electrophoretic system containing the samples were placed into a buffer solution with $\mathrm{pH}$ of $8.3(50 \mathrm{mM}$ Tris, $0.384 \mathrm{M}$ Glycine, $5 \mathrm{mM}$ ethylenediaminetetraacetate (EDTA), $\mathrm{pH} 8.8$ and $0.25 \%$ SDS). The electrophoretic run was performed at $80 \mathrm{~V}$, for 15 hours. Afterwards, the gels were stained with $0.1 \%$ Coomassie blue, according to Alfenas (1998), for $12 \mathrm{~h}$ and discolored with a solution of $10 \%$ acetic acid, $45 \%$ methanol, and $45 \%$ distilled water.

The analysis of protein fractions bands was qualitative, where the presence or absence of bands and the increases or decreases of their intensity were visually identified for each different seed quality assessment methods used.

\section{Results and Discussion}

At beginning of experiment, seeds of $H$. albus had moisture content of $7.9 \%$, which remained constant during the following months.

Handroanthus albus seed germination was favored by storage periods of three to six months with values of $88 \%$ and $84 \%$, respectively (Figure 1). Percent germination of freshly harvested seeds was $72 \%$ and had an increase during the six initial months of storage, but from this point on a gradual reduction on germination was observed, reaching $18 \%$ at 12 months. Changes on percent of germination have already been found by other authors for different species within the same genus. Kano et al., (1978) have observed that the germination of seed of the Golden Trumpet Tree Tabebuia chrysotricha (Mart. Ex DC.) after 15 days storage under dry chamber conditions, has decreased percentage of germination from $78 \%$ to $63 \%$ in 30 days, and again increased to $85 \%$ in 63 days. For seeds of the Purple Trumpet Tree [Tebebuia impetiginosa (Mart. Ex DC) Stanley], Mello and Eira (1995) have observed a $15 \%$ increase on germination of seeds stored during 18 months at $-29^{\circ} \mathrm{C}$.

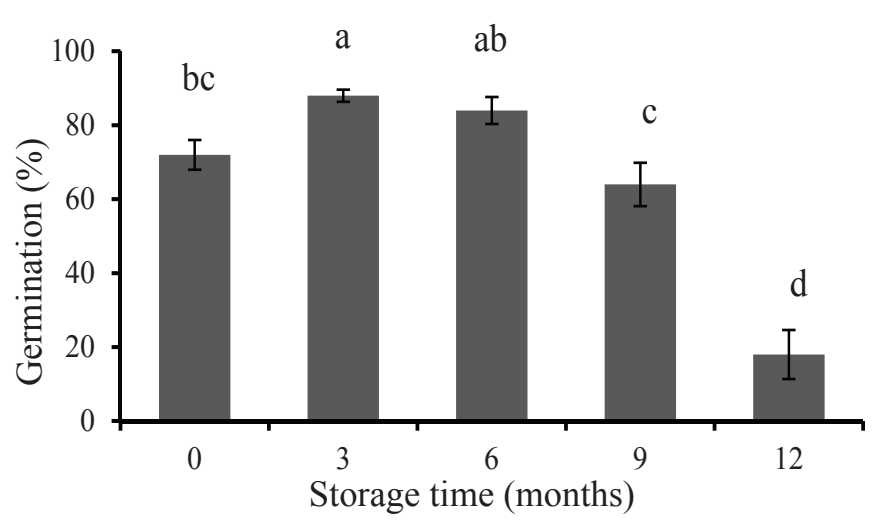

Figure 1. Percent germination of seeds of Handroanthus albus as a function of storage periods under cold chamber conditions $\left( \pm 8{ }^{\circ} \mathrm{C} ; \mathrm{RH} \pm 40 \%\right)$ during 0 (control), 3, 6, 9, and 12 months. Letters on top of columns are referent to comparison of treatment means by Tukey test, at $5 \%$ probability. Columns topped by the same letter do not differ statistically between each other.

Among factors causing changes on percent germination during storage are: initial quality of seeds; maturation degree at harvest moment; presence or absence of microorganisms; environmental conditions, and packages used (Carvalho and Nakagawa, 2000; Marcos-Filho, 2005). Other factors causing changes on germination are the phenolic compounds, which are present in the seed tegument and can act as germination inhibitors (Bewley e Black, 1994), or the presence of proteins during storage that can be expressed under stress conditions, such as high temperatures (Vierling, 1991).

Based on changes of percent of germination during the storage process, biochemical changes on proteins profile and their close correlations with the increases or decreases of seed germination were analyzed. For the results on profile of proteins (Figure 2), it was found a $60 \mathrm{kDa}$ band for storage periods of six and nine months that coincided with the decrease of $20 \%$ on germination percentage. For 
the remaining bands, the general profile of proteins did not differ statistically among storage periods, with emphasis in the high intensity of proteins with $50.6 \mathrm{kDa}, 40.6 \mathrm{kDa}$, and $27.8 \mathrm{kDa}$. Such abundance on proteins profile was a particular characteristic of the assessments performed within this study, since only in a small number of studies this correlation is done. Some research works have already mentioned the presence of $10 \mathrm{kDa}$ proteins in seeds freshly harvested or after storage (Silva et al., 2011) as well during their development, as reported by Carvalho et al. (2008) in a study carried out with Tabebuia serratifolia.

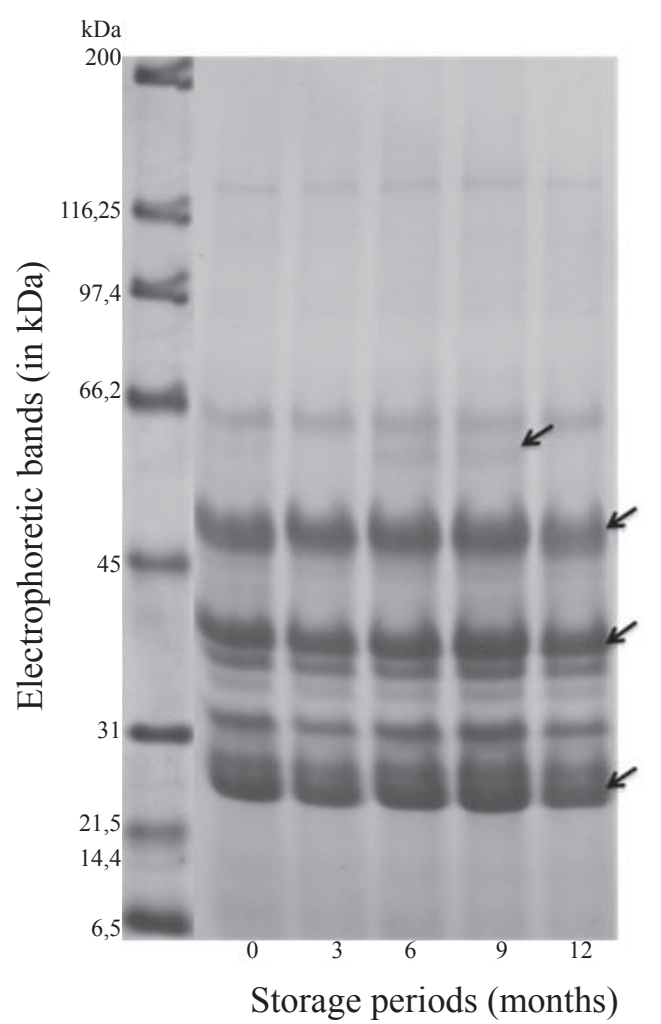

Figure 2. Electrophoretic profile of reserve proteins of seeds of Handroanthus albus as a function of storage periods during 0 (control), 3. 6, 9, and 12 months under cold chamber conditions $\left( \pm 8^{\circ} \mathrm{C} ; \mathrm{RH} \pm 40 \%\right)$.

To better understand changes during storage, the accelerated aging test was performed for each storage period, aiming at a more detailed assessment of changes of physiological and biochemical characteristics of seeds based on the profile of reserve proteins.

The accelerated aging process did not induce changes on germination of freshly harvested seeds or on those seeds stored for three months (Figure 1A and 1B). After storage periods of nine and 12 months, however, the accelerated aging favored seed germination (Figure 1E).

Increases on germination were also observed for seed of the noble wood tree Cedrella fissilis Vellozo after $72 \mathrm{~h}$ of accelerated aging (Borges et al., 1990). Likewise, Schmidt (2000) has stressed that the high moisture content during accelerated aging can activate the mechanism of cell repair, what was also observed for seeds of peanuts (Arachis hypogacea L.)

For all storage periods, data on artificial aging of 72 and $96 \mathrm{~h}$ showed a percent of germination around $80 \%$, thus demonstrating that accelerated aging favored seed germination when compared to seeds stored for 12 months or non-aged seeds (18\%). The remaining periods of accelerated aging for seeds subjected to distinct storage periods have presented irregular behavior, with increases and decreases depending on the period of storage assessed (Figure 3).

The storage period of 12 months, when associated to the accelerated aging of $72 \mathrm{~h}$ induced a $65 \%$ increase on percent of germination, in relation to non-aged seeds or seeds aged for a $24 \mathrm{~h}$ period. These results show the dependence on artificial aging of seeds during a $72 \mathrm{~h}$ period in order to achieve such increase on germination percentage when these seeds are stored for long periods (Figure 3E).

Because of high influence of artificial aging on germination rate of seeds stored for 12 months, the profile of proteins was assessed within the different aging periods.

An increase on intensity of bands of $30.2 \mathrm{kDa}$ and $27.8 \mathrm{kDa}$ was observed, coinciding with an increase on percent of germination (34\%, between 48 and $72 \mathrm{~h}$ of aging time) and a decrease on intensity for the bands of $39 \mathrm{kDa}$ and $32 \mathrm{kDa}$, as a function of the increased aging time (from $24 \mathrm{~h}$ until $96 \mathrm{~h}$ ) (Figure 4). A band of $19 \mathrm{kDa}$ was also detected. In a general way, this low molecular weight protein may correspond to a particular group of proteins denominated "thermal shock proteins" that are directly related to thermic stresses (Waters et al., 1996), such as the high temperature $\left(42{ }^{\circ} \mathrm{C}\right)$ to which seeds were subjected during the aging process.

In studies with seeds of Crimson clover (Trifolium incarnatum L.) and Perennial Ryegrass (Lolium perenne L.), Ching and Schoolcraft (1968) reported reduction on protein content only after seed viability loss and that for both species the protein loss was dependent on the severity of storage conditions. Pereira (1980), however, did not find a defined trend on the behavior of proteins during storage 
of seeds of the hardwood Rubber Tree [Hevea brasiliensis (Willd.) Muell.-Arg.], and observed an intermittent variation among treatments.

The variation found on protein profile within this study may be a response of seeds to extreme temperatures. Under such conditions, the thermal shock protein is produced. This protein is synthesized in temperatures higher than $30^{\circ} \mathrm{C}$ and contributes for the maintenance of the integrity of cellular membranes (Marcos-Filho, 2005). Such protein has considerable heterogeneity in isoelectric points, molecular weight, stability, and expression level (Lee et al., 1994). In order to correlate such proteins with results herein obtained, further detailed studies are necessary. For example: analysis of protein profiles by 2-D electrophoresis; immunolocalization of specific antibodies at reaction level; and gene expression, aiming at verifying specific involvements of this group of proteins with characteristics of germination of $H$. albus seeds.

$$
\text { A }
$$
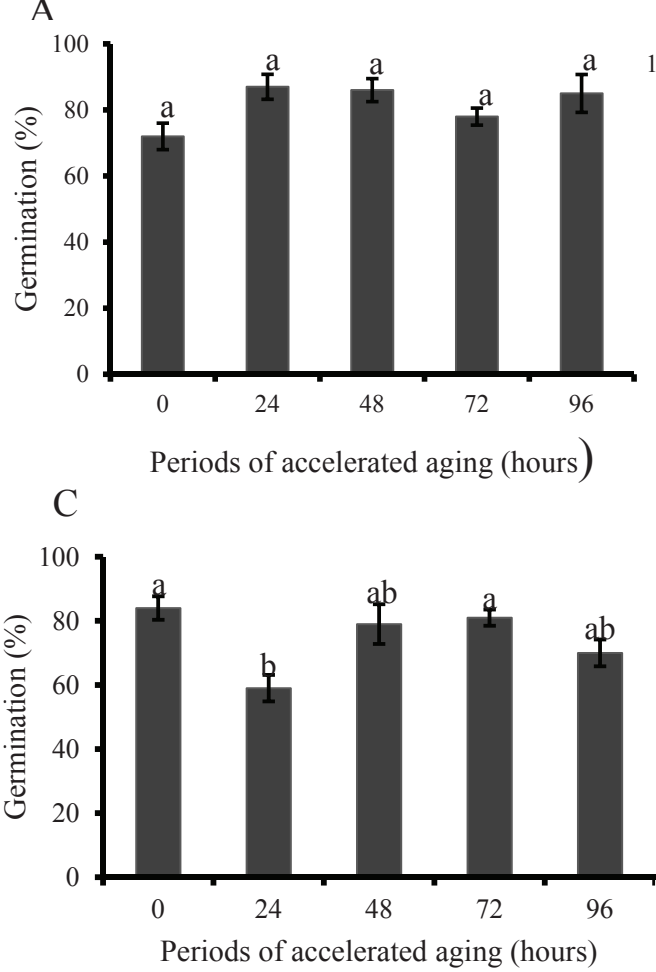

B

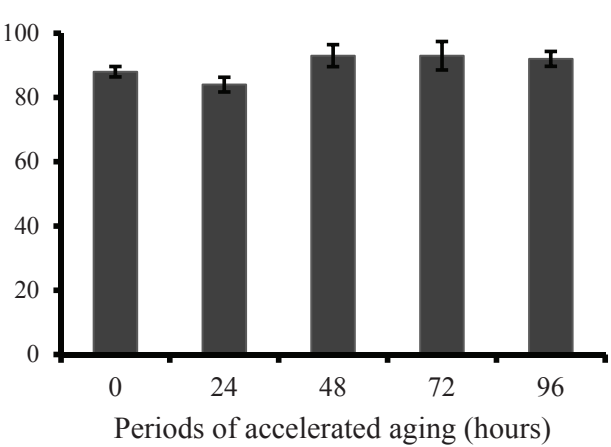

$\mathrm{D}$
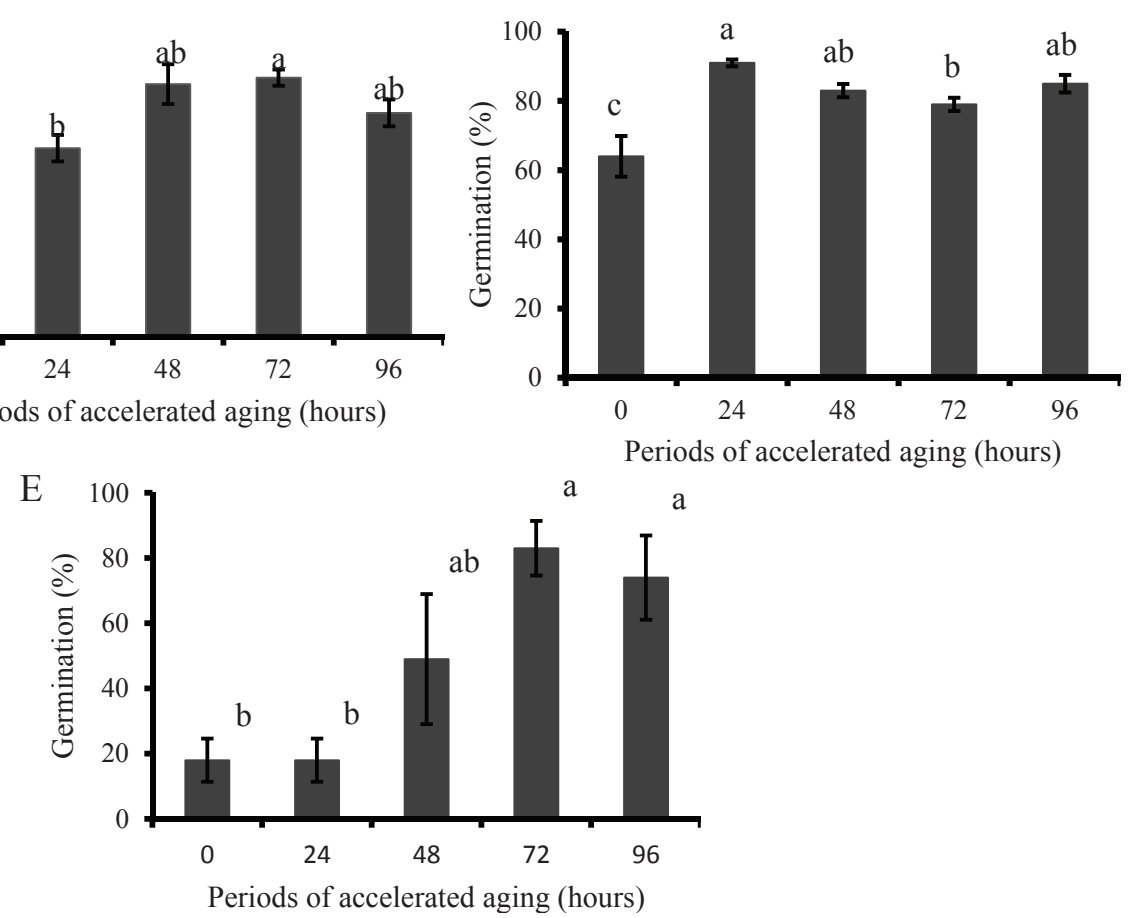

Figure 3. Percentage of germination of freshly harvested seeds of Handroanthus albus (A) and after storage periods of 3 (B), 6 (C), 9 (D), and 12 (E) months under cold chamber conditions $\left( \pm 8^{\circ} \mathrm{C} ; \mathrm{RH} \pm 40 \%\right)$, in function of accelerated aging periods of 0 (control), 24, 48, 72, and 96 hours. Letters on top of columns are referent to comparison of treatment means by Tukey test, at $5 \%$ probability. Columns topped by the same letter do not differ statistically between each other. 


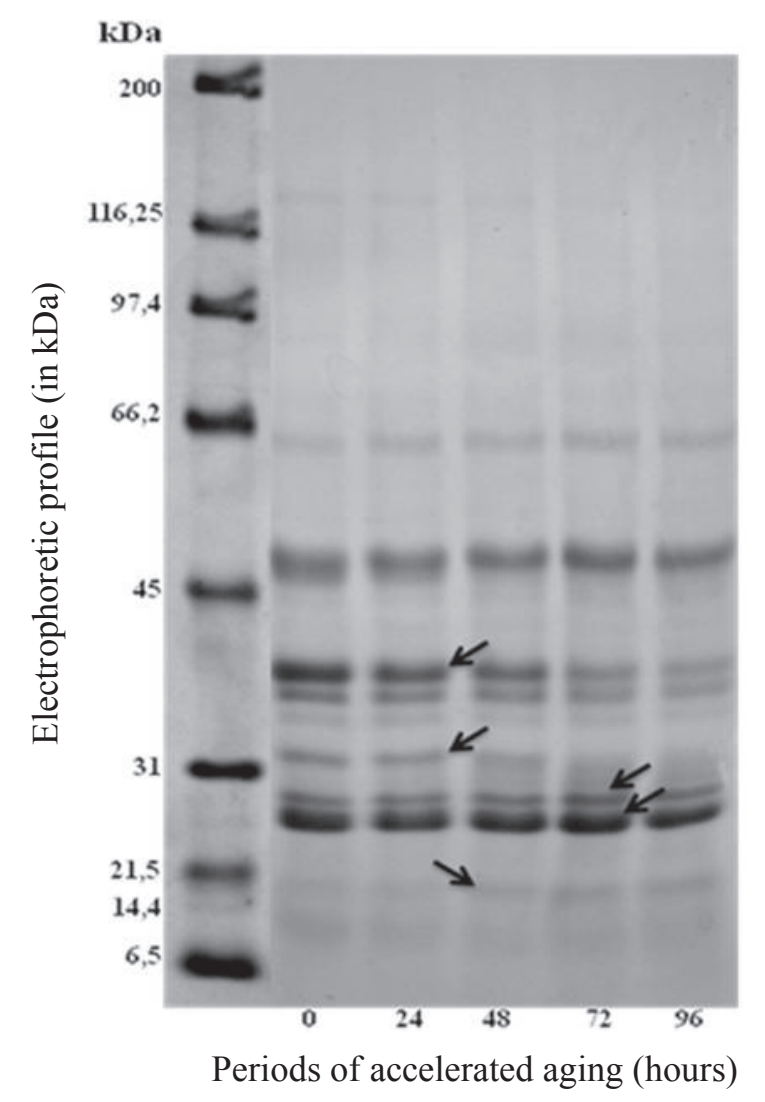

Figure 4. Electrophoretic profile of reserve proteins of seeds of Handroanthus albus stored during 12 months under cold chamber conditions $\left( \pm 8^{\circ} \mathrm{C}\right.$; $\mathrm{RH} \pm 40 \%)$ and then subjected to different periods of accelerated aging of 0 (control), 24, 48, 72, and 96 hours. The electrophoretic run was performed in polyacrylamide gel SDS-PAGE (at $80 \mathrm{~V}$; for $15 \mathrm{~h}$ ).

\section{Conclusions}

The germination of not artificially aged seeds of Handroanthus albus is favored by storage in cold chamber during three or six months.

Storage of seeds of Handroanthus albus during nine or 12 months when associated to accelerated aging of 24 or 48 hours, respectively, increases germination rate. The proteins of $39 \mathrm{kDa}, 32 \mathrm{kDa}, 30.2 \mathrm{kDa}, 27.82 \mathrm{kDa}$, and 19 $\mathrm{kDa}$ may be associated to these increases and need to be better studied for this species.

\section{References}

AIAZZI, M.T.; ARGUELlO, J.A.; PEREZ, A.; DI RIENZO, J.; GUZMÁN, A. Deterioration in Atriplex cordobensis (Gandoger et
Struckert) seeds: natural and accelerated ageing. Seed Science and Technology, v.25, n.1, p.147-155, 1996.

AL-NIEMI, T.S.; STOUT, R.G. Heat-shock protein expression in a perennial grass commonly associated with active geothermal areas in western North America. Journal of Thermal Biology, v. 27, n.6, p.547553, 2002. http://www.ren.montana.edu/pubs/pdf/2002/heat-shock\%20 protein $\% 20$ expression $\% 20 \mathrm{in} \% 20 \mathrm{a} \% 20$ perennial $\% 20$ grass $\% 20$.pdf

ALFENAS, A.C. Eletroforese de isoenzimas e proteinas afins: fundamentos e aplicações em plantas e microrganismos. Viçosa: UFV, 1998. 574p.

BETTEY, M.; FINCH-SAVAGE, W.E. Stress protein content of mature Brassica seeds and their germination performance. Seed Science Research, v.8, n.3, p.347-355, 1998.

BEWLEY, J.D.; BLACK, M. Seeds: physiology of development and germination. New York: Plenum, 1994. 445p.

BORGES, E.E.L.; CASTRO, J.L.D.; BORGES, R.C.G. Avaliação fisiológica de sementes de cedro submetidas ao envelhecimento precoce. Revista Brasileira de Sementes, v.12, n.1, p.56-62, 1990. http://www. abrates.org.br/revista/artigos/1990/v12n1/artigo04.pdf

BRASIL. Ministério da Agricultura, Pecuária e Abastecimento. Regras para análise de sementes. Ministério da Agricultura, Pecuária e Abastecimento. Secretaria de Defesa Agropecuária. Brasília: MAPA/ ACS, 2009. 395p.http://www.agricultura.gov.br/arq_editor/file/ Laborat\%C3\%B3rio/Sementes/Regras\%20para\%20Analise\%20de\%20 Sementes.pdf

CABRAL, E.L.; BARBOSA, D.C.A.; SIMABUKURO, E.A. Armazenamento e germinação de sementes de Tabebuia áurea (manso) Benth. \& Hook. f. ex. S. Moore. Acta Botanica Brasilica, v.17, n.4, 2003. http://www.scielo.br/pdf/abb/v17n4/a13v17n4.pdf

CAMARGO, M.L.P.; MORI, E.S.; MELLO, E.J.; ODA, S.; LIMA, G.P. Atividade enzimática em plântulas de Eucalyptus grandis provenientes de sementes envelhecidas artificialmente e naturalmente. Ciência Florestal, v.10, n.2, p.113-122, 2000. http://redalyc.uaemex.mx/pdf/534/53400209.pdf

CARVALHO, M.L.M.; NERY, M.C. OLIVEIRA, L.M.; HILHORST, H.W.M.; GUIMARÃES, R.M. Morphophysiological development of Tabebuia serratifolia Vahl Nich. seeds. Scientia Agricola, v.65, n.6, p.643-651, 2008. http://www.scielo.br/pdf/sa/v65n6/12.pdf

CARVALHO, N.M.; GOES, M.; AGUIAR, I.B.; FERNANDES, P.D. Armazenamento de sementes de ipê-amarelo (Tabebuia chrysotricha). Cientifica, v.4, n.3, p.315-319, 1976.

CARVALHO, N.M.; NAKAGAWA, J. Sementes: ciência, tecnologia e produção. 4ed. Jaboticabal: FUNEP, 2000, 588p.

CARVALHO, P.E.R. Espécies Arbóreas Brasileiras, Brasília: EMBRAPA, 2003. 1039p.

CHING, T.M.; SCHOOLCRAFT, I. Physiological and chemical 
differences in aged seeds. Crop Science, v.8, n.4, p.407-409, 1968.

CUNHA, R.; SALOMÃO, A.N.; EIRA, M.T.S.; MELLO, C.M.C.; TANAKA, D.M. Métodos para conservação a longo prazo de sementes de Tabebuia spp. - Bignoniaceae. Revista do Instituto Florestal, v.4, n.4, p.675-678, 1992.

DELL'AQUILA, A.; DI TURI, M. Amplification of ageing symptoms in two differently thermal-sensitive wheat (Triticum durum L.) genotypes by heat117 shock: relationship between germination response and embryo protein patterns. Seed Science and Technology, v.27, n.2, p.467476, 1999.

DELL'AQUILA, A.; SPADA, P. Effect of low and high temperatures on protein synthesis patterns of germinating wheat embryos. Plant Physiology Biochemistry, v.32, n.1, p.65-73, 1994.

FIGLIOLIA, M.B. Conservação de sementes de essências florestais. Boletim Técnico do Instituto Florestal de São Paulo, v.42, p.1-18, 1988.

FIGLIOLIA, M.B.; SILVA, A.; JARDIM, D.C.P.; IWANE, M.S.S. Viabilidade de sementes liofilizadas de essências florestais nativas. Silvicultura em São Paulo, v.20/22, p.47-55, 1988.

GANGULI, S.; SEN-MANDI, S. Some physiological differences between naturally and artificially aged wheat seeds. Seed Science and Technology, v.18, n.3, p.507-514, 1990.

GASHAW, M.; MICHELSEN, A. Influence of heat shock on seed germination of plants from regularly burnt savanna woodlands and grasslands in Ethiopia. Plant Ecology, v.159, n.1, p.83-93, 2002.

GROSE, S.O.; OLMSTEAD, R.G. Taxonomic Revisions in the Polyphyletic Genus Tabebuia s. 1. (Bignoniaceae). Systematic Botany, v.32, n.3, p.660-670, 2007. http://depts.washington.edu/phylo/ OlmsteadPubs/Grose_Olmstead_2007b.pdf

JENG, T.L.; SUNG, J.M. Hydration effect on lipid peroxidation activity of artificially aged peanut seed. Seed Science and Technology, v.22, n.3, p.531-539, 1994.

KAGEYAMA, P.Y.; SANCHEZ, S.P.A.; FERRAZ, E.M.; SOUZA, L.M.C. Armazenamento de sementes de três espécies nativas (Tabebuia heptaphylla, Erytrhina verna e Chorisia speciosa). Revista do Instituto Florestal, v.4, p.435-439, 1992.

KANO, N.K.; MARQUÉZ, F.C.M.; KAGEYAMA, P.Y. Armazenamento de sementes de ipê-dourado (Tabebuia sp). IPEF, n.17, p.13-23, 1978. http://www.ipef.br/publicacoes/scientia/nr17/cap02.pdf

KHAN, M.M.; HENDRY, G.A.F.; ATHERTON, N.M.; VERTUCCIWALTERS, C.W. Free radical accumulation and lipid peroxidation in testas of rapidly aged soybean seeds: a light-promoted process. Seed Science Research, n.6, n.3, p.101-107, 1996.

KOROTAEVA, N.E.; ANTIPINA, A.I.; GRABELNYKH, O.I.; VARAKINA, N.N.; BOROVSKII, G.B.; VOINIKOV, V.K. Mitochondrial low-molecular weight heat-shock proteins and the tolerance of cereal mitochondrial to hyperthermia. Russian Journal of Plant Physiology, v.48, n.6, p.798-803, 2001.

LAEMMLI, U.K. Cleavage of structural proteins during the assembly of the head of bacteriophage T4. Nature, v.227, p.680-685, 1970.

LEE, Y-R.J.; NAGAO, R.T.; KEY, J.L. A soybean 101-kD Heat shock protein complements a yeast HSP104 deletion mutant in acquiring thermo tolerance. The Plant Cell, v.6, p.1889-1897, 1994.

LORENZI, H. Árvores brasileiras: manual de identificação e cultivo de plantas arbóreas do Brasil. 4.ed. Nova Odessa: Instituto Plantarum, 2002. 384p.

MA, Y.; BLISS, F.A. Seed proteins of common bean. Crop Science, v.18, p.431-437, 1978.

MACHADO-NETO, N.B.; CUSTÓDIO, C.C.; TAKAKI, M. Evaluation of naturally and artificially aged seeds of Phaseolus vulgaris L. Seed Science and Technology, v.29, n.1, p.137-149, 2001.

MAEDA, J.A.; MATTHES, L.A.F. Conservação de sementes de ipê. Bragantia, v.43, n.1, p.45-50, 1984. http://www.scielo.br/scielo. php?script=sci_arttext\&pid=S0006-87051984000100006

MARCOS FILHO, J. Fisiologia de sementes de plantas cultivadas. Piracicaba: FEALQ, 2005. 495p.

MELLO, C.M.C.; EIRA, M.T.S. de. Conservação de sementes de ipês (Tabebuia spp.). Revista Árvore, v.19, n.4, p.427-432, 1995.

PEREIRA, J.P. Conservação da viabilidade do poder germinativo da semente de seringueira. Pesquisa Agropecuária Brasileira, v.15, n.2, p.237-244, 1980.

PINTO, M.M.; SADER, R.; BARBOSA, J.M. Influência do tempo de secagem e do armazenamento sobre a viabilidade das sementes de ipêrosa. Revista Brasileira de Sementes, v.8, p.37-47, 1986 http://www. abrates.org.br/revista/artigos/1986/v8n1/artigo03.pdf

SCHMIDT, L. Guide to handling of tropical and subtropical Forest seed. Danida Forest Seed Centre, 2000. 511p.

SHIBATA, M.; COELHO, C.M.M.; OLIVEIRA, L.M.; GUIDOLIN, A.F. Padronização metodológica para determinação de proteínas de reserva de sementes de Handroanthus albus (Chamiso). Revista de Ciências Agroveterinárias, v.10, n.2, 2011. http://rca.cav.udesc.br/ rca_2011_2/8\%20Shibata\%20et\%20al.pdf

SILVA, D.G.; CARVALHO, M.L.M.; NERY, M.C.; OLIVEIRA, L.M.; CALDEIRA, C.M. Alterações fisiológicas e bioquímicas durante o armazenamento de sementes de Tabebuia serratifolia. Revista Cerne, v.17, n.1, p.1-7, 2011. http://www.dcf.ufla.br/cerne/administracao/ publicacoes/m502v17n1o1.pdf

SPINOLA, M.C.M.; CICERO, S.M.; MELO, M. Alterações bioquímicas e fisiológicas em sementes de milho causadas pelo envelhecimento acelerado. Scientia Agricola, v.57, n.2, p.263-270, 2000. http://www. scielo.br/pdf/sa/v57n2/v57n2a11.pdf 
SUN, W.; MONTAGU, M. V.; VERBRUGGEN, N. Small heat shock protein and stress tolerance in plants. Biochimica at Biophysica Acta, v.1577, p.1-9, 2002.

VIERLING, E. The role of heat shock proteins in plants. Annual Review of Plant Physiology and Plant Molecular Biology, v.42, p.579-620, 1991.
WATERS, E.R.; LEE, G.J.; VIERLING, E. Evolution, structure and function of the small heat shock proteins in plants. Journal of Experimental Botany, v.47, n.3, p.325-338, 1996. http://jxb.oxfordjournals.org/ content/47/3/325.full.pdf + html 